\title{
PERAN ORANG TUA DALAM MENDIDIK ANAK DITINJAU DARI HUKUM ISLAM
}

\section{Darmawansyah}

\begin{abstract}
The formation of personality is very meaningful, parents as the first personal coach in a child's life. Parenting activities are not only how parents treat children, but how parents educate, guide and protect children from childhood to adulthood in accordance with the values, norms and culture of the community. Parenting children in Islamic law (hadhanah) is the responsibility of both parents who should get special attention as; take care of, care for, educate and raise children who are still small and cannot take care of themselves, also parents should supervise children who are aged 7-18 years (adolescents) or the period after mumayyiz of things that are prohibited by Shari'ah, other than that in carrying out the duties of his hadhanah every parent must always be guided by Islamic rules based on the Qur'an and Al-Hadith.
\end{abstract}

Keywords: Role of Parents in Educating Children

\section{PENDAHULUAN}

Keluarga adalah lingkungan yang pertama dan utama dikenal oleh anak. Alasannya, institusi terkecil dalam masyarakat ini telah mempengaruhi perkembangan individu anggota-anggotanya, termasuk anak. Kelompok inilah yang melahirkan individu dengan berbagai bentuk kepribadiannya di masyarakat. Oleh karena itu tidaklah dapat dipungkiri bahwa sebenarnya keluarga mempunyai fungsi yang tidak hanya terbatas sebagai penerus keturunan saja. ${ }^{1}$

Ketika anak dilahirkan setiap orang tua sangat menginginkan agar anak tersebut menjadi anak yang saleh. Untuk mewujudkan itu semua, maka proses pendidikan yang dijalani anak harus juga benar. Tugas ayah dan Ibu tidak hanya menyediakan perlindungan, makan, dan pakaian saja, akan tetapi tetapi 10.

${ }^{1}$ Mardiya,Kiat Kiat Khusus Membangun Keluarga Sejahtera (Jakarta: BKKBN, 2002), 
bertanggungjawab dalam memberikan perlindungan emosi dan keselamatan dari pengaruh-pengaruh negatif terhadap anak.

Pendidikan dasar yang diberikan oleh ayah dan ibu dan ajaran agama yang kukuh sangat penting untuk menghindari gejala-gejala yang tidak di inginkan. Jadi lingkungan keluarga sangat berpengaruh bagi kehidupan anak. Bukan saja derajat kemuliaan, melainkan lebih dari itu, derajat tanggung jawab dalam keluarga. ${ }^{2}$

Adapun fungsi dan tugas perempuan sesuai dengan kodrat kewanitaanya antara lain.

\section{Sebagai Ibu Rumah Tangga}

Perempuan (isteri) adalah pemimpin dalam urusan rumah tangga. sedangkan suami adalah pemimpin dalam urusan keluarga. Dalam prakteknya, kepemimpinan dan tugas-tugas keluarga itu lebih banyak dilakukan oleh pihak perempuan. Dengan kelemah-lembutanya, seorang perempuan sebagai ibu rumah tangga dapat berperan sebagai faktor penyeimbang kaum laki-laki dalam kehidupan keluarga. Peran istri bisa membantu suaminya dalam mengurus rumah dan anak-anak. ${ }^{3}$

\section{Sebagai isteri dari Suami}

Setiap ibu ketika menikah pasti bercita-cita untuk segera hamil dan melahirkan anak, dan ini merupakan kodrat setiap perempuan yang tidak mudah dijalani, karena dibutuhkan perjuangan dan kesabaran dari perempuan. Ketika hamil, ia menanggung sakit yang tak terperikan mempertaruhkan nyawanya antara hidup dan mati rumah tangga sebagai kerajaan kecil dari suatu keluarga, memang sudah selayaknya dipimpin oleh seorang laki-laki, karena laki-laki bisa menjadi imam dalam keluarga. Namun demikian, derajat kepemimpinan laki-laki atas perempuan. Keluarga adalah lingkungan yang pertama dan utama dikenal oleh anak. Alasannya, institusi terkecil dalam masyarakat ini telah mempengaruhi perkembangan individu anggota-anggotanya, termasuk anak. ${ }^{4}$

\footnotetext{
${ }^{2}$ Ibid, 11 .

${ }^{3}$ Hasbi Indra Dkk, Potret Wanita Shalehah (Jakarta: Pernamadani, 2004), 5-8.

${ }^{4}$ Ibid.,
} 
Kelompok inilah yang melahirkan individu dengan berbagai bentuk kepribadiannya di masyarakat. Oleh karena itu tidaklah dapat dipungkiri bahwa sebenarnya keluarga mempunyai fungsi yang tidak hanya terbatas sebagai penerus keturunan saja. Ketika anak dilahirkan yang terbesit dalam hati adalah keinginan agar anak tersebut menjadi anak yang saleh. Untuk mewujudkan itu semua, maka proses pendidikan yang dijalani anak harus pendidikan yang benar.

Allah Swt telah menggariskan sesuatu yang sangat istimewa bagi kaum perempuan. Ia telah memberikan kepada mereka sisi emosional dan perasaan yang lebih kuat dibanding dengan sisi rasionalitas. Oleh karena itu, kita melihat seorang ibu yang melalui hari-harinya di samping putranya yang sedang terbaring sakit. Mereka masih dapat bertahan untuk hidup dan merasakan beban berat yang menghimpit suami dan anak-anaknya ketika mereka harus melalui masa krisis. Di samping itu, ia juga mampu mengatasi bagaimana sulitnya mendidik dan membesarkan anak. ${ }^{5}$

Adapun peran suami dalam keluarganya antara lain sebagai berikut :

\section{Sebagai Kepala Keluarga dan Ayah}

Menjadi seorang ayah sekaligus sebagai pemimpin dalam keluarga. Begitu pentingnya peran ayah, sebagai sosok panutan untuk anak-anaknya, maka Seorang ayah yang baik tentu akan memberikan sebuah suri tauladan yang baik bagi anak-anaknya.

\section{Pemberi Nafkah}

Nafkah adalah harta yang dikeluarkan oleh suami untuk isteri dan anak-anaknya berupa makananan, pakaian, tempat tinggal dan hal lainnya. Menjadi seorang ayah adalah kebanggaan bagi setiap laki-laki, karena menjadi seorang ayah adalah sebuah anugrah yang tak terkira harganya.

Pembagian peran antara laki-laki dan perempuan atau suami dan isteri menurut pandangan konvensional, berada pada dua wilayah. Wilayah private yakni meliputi rumah tangga termasuk urusan dapur diserahkan kepada

${ }^{5}$ Syaikh Mutawalli Asya'rawi, Fikih Perempuan (Muslimah) Busana Dan Perhiasan, Penghormatan Atas Perempuan, Sampai Wanita Karier (Jakarta: Amzah, 2003), 144. 
256 | MUSA WA, Vol. 11 No. 2 Desember 2019 : 253 - 288

perempuan. Sementara wilayah buplik yang terdiri dari kantor, ranah politik, musyawarah desa, perdagangan, pertanian,dan lain-lain tanggung jawab lakilaki. Laki-laki diharapkan sebagai tumpuan keluarga dalam mencari nafkah. Sedangkan perempuan dianggap sebagai pendukung laki-laki yang berperan penting dalam urusan rumah tangga. Sekalipun pembagian peran ini masih belum mencapai puncak kesetaraan tetapi dalam tatanan masyarakat pembagian peran ini setidaknya dianggap sebagai bentuk keseimbangan antara tugas laki-laki dan perempuan ${ }^{6}$

Seorang suami adalah imam bagi istri, kepala keluarga, dan kepala sekolah bagi anak-anaknya. Maka seorang suami yang kompeten wajib memberikan bimbingan agama kepada istrinya, agar keimanan mereka semakin bertambah baik. Dan dengan begitu maka suami adalah panutan bagi istri dan anak-anaknya. Maka sangat diharapkan jika suami yang ideal adalah dia yang memiliki keimanan lebih baik dari pada isterinya.

Suami sebagai kepala keluarga berkewajiban untuk bekerja dengan baik melalui usaha yang baik dan halal. Karena itulah, seorang laki-laki menjadi pemimpin keluarga, sebagaimana firman Allah dalam QS: Al-Nisa' [4]: 34

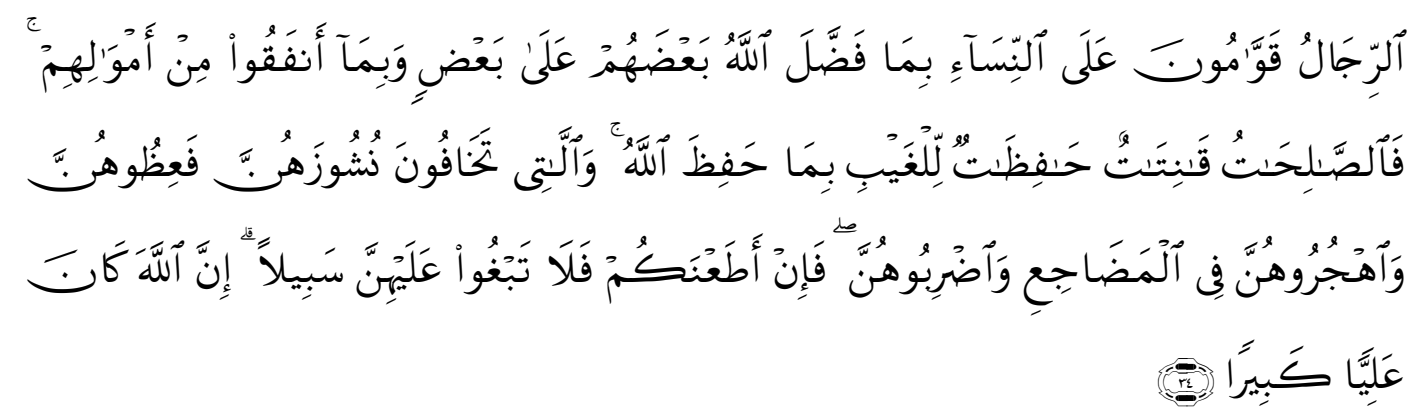

Terjemahnya:

"Kaum laki-laki itu adalah pelindung bagi kaum perempuan, oleh karena Allah telah melebihkan sebahagian mereka (laki-laki) atas sebahagian yang lain perempuan, dan karena mereka (laki-laki) telah menafkahkan sebagian dari harta mereka. Sebab itu maka wanita yang saleh, ialah yang taat kepada Allah lagi memelihara diri ketika suaminya tidak ada, oleh karena Allah telah memelihara (mereka). Wanita-wanita yang kamu khawatirkan Nusyu'z-nya, maka nasehatilah mereka dan pisahkanlah mereka di tempat tidur mereka, dan pukullah mereka. Kemudian jika mereka mentaatimu,

${ }^{6}$ Abdul Monir Yacoob dan Siti Shamsiah, Hukum Keluarga Islam (Jakarta: Kencana, 2006), 23. 
maka jangalah kamu mencari-cari jalan untuk menyusahkannya. Sesungguhnya Allah Maha Tinggi lagi Maha Besar."7

Berdasarkan QS: Al-Nisa' [4]: 34 telah dijelaskan bahwa suami adalah pemimpin sekaligus juga sebagai pelindung bagi isterinya. Serta perempuanperempuan yang shāleha adalah mereka yang taat kepada Allah dan menjaga diri ketika suaminya tidak ada. Maksudnya menjadi pemimpin pula bagi dirinya sendiri dan bagi anak-anaknya ketika suaminya tidak ada. Selain itu wanita juga harus terus berusaha untuk meningkatkan kualitas dirinya. Karena untuk mencetak generasi yang berkualitas, dibutuhkan pendidik yang berkualitas pula. Hal itu berarti seorang wanita tidak boleh berhenti belajar. ${ }^{8}$

Suami dalam menjalankan perannya di dalam keluarga apabila tidak bisa memberikan nafkah yang cukup kepada isteri dan anak-anaknya, maka dari itu isterilah yang berkerja. Istri yang berkerja menimbulkan masalah ketidakharmonisan dalam suatu keluarga. Banyak isteri harus bekerja karena peran suami tidak dijalankan dengan baik. Maka isteri ini bukan hanya mengurus rumah tangga tapi juga harus bekerja. Akibatnya beban isteri bertambah menjadi beban ganda (double burden).

Tugas suami dan isteri bukan hanya berkisar sekitar menyediakan perlindungan, makan, dan pakaian saja tetapi bertanggung jawab juga memberikan perlindungan emosi dan keselamatan dari pengaruh-pengaruh negatif. Pendidikan dasar yang diberikan oleh suami dan isteri terutama ajaran agama yang baik, sangat penting untuk menghindari gejala-gejala yang tidak diinginkan, karena lingkungan keluarga berperan penting dalam memberikan pengaruh bagi kehidupan anak-anak mereka.

Rumah tangga sebagai tempat pembinaan dari suatu keluarga, maka sudah seharusnya dibina oleh seorang suami yang bijaksana, karena suami bisa menjadi imam dalam keluarga. Namun demikian, derajat kepemimpinan suami atas isteri bukanlah saja derajat kemuliaan, melainkan lebih kepada derajat tanggung jawab dalam keluarga.

${ }^{7}$ Departemen Agama RI, Alqur'an dan Terjemahnya (Jakarta: Toha Putra, 1999), 129.

${ }^{8}$ M. Qurais Shihab, Tafsir Al-Misbah (Jakarta: Lentera, 2000), 505-410. 
258 | MUSA WA, Vol. 11 No. 2 Desember 2019 : 253 - 288

Dalam karya ilmiah penulis akan mengungkapkan Peran Orang Tua dalam Mendidik Anak Ditinjau dari Hukum Islam dengan menggunakan studi kepustakaan dengan pendekatan Hukum Islam. Dengan pokok bahasan penelitian ini adalah bagaimana Peran Orang Tua Dalam Mendidik Anak Ditinjau dari Hukum Islam.

\section{PEMBAHASAN}

\section{Teori Pola Asuh Anak}

Pola asuh terdiri dari dua kata yaitu "Pola" dan "Asuh" yang berarti corak, model, sistem, cara kerja, bentuk (struktur) yang tepat. Sedangkan kata asuh dapat berarti menjaga (merawat dan mendidik) anak kecil, membimbing, (membantu melatih dan sebagainya) dan memimpin (menggapai dan menyelenggarakan) satu badan atau lembaga. ${ }^{9}$ kata asuh adalah mencakup segala aspek yang berkaitan dengan pemeliharaan, perawatan, dukungan dan bantuan sehinggan orang tetap berdiri dan menjalani hidupnya secara sehat. ${ }^{10}$

Menurut Ahmad Tafsir, pola asuh berarti pendidikan, sedangkan pendidikan adalah bimbingan secara sadar oleh pendidik terhadap perkembangan jasmani dan rohani anak didik menuju terbentuknya kepribadian yang utama. ${ }^{11}$ Gunarso mengatakan bahwa:

Pola asuh merupakan cara orang tua bertindak, berinteraksi, dan membimbing anak sebagai suatu aktivitas yang melibatkan banyak perilaku tertentu secara individual maupun bersama-sama sebagai serangkaian usaha aktif untuk mengarahkan anak. ${ }^{12}$ Pengertian lain tentang pola asuh terhadap anak adalah bentuk interaksi antara anak dengan pengasuh selama mengadakan kegiatan pengasuhan yang berarti pengasuh mendidik, membimbing dan mendisiplinkan serta melindungi anak untuk mencapai kedewasaan sesuai dengan norma-norma yang berlaku dalam lingkungan setempat dan masyarakat. ${ }^{13}$

${ }^{9}$ TIM Penyusun Kamus Pusat Pembinaan dan Pengembangan Bahasa, Kamus Besar Bahasa Indonesia (Jakarta, Balai Pustaka, 1988 ), 92.

${ }^{10}$ Elaine Donelson, Asih, Asah, Asuh, dan Keutamaan Wanita (Yogyakarta: Kanisius, 1990), 5.

${ }^{11}$ Danny I. Yatim Irwanto, Kepribadian Keluarga Narkotika (Jakarta: Arcan, 1991), 94.

${ }^{12}$ Yulia Singgih D. Gunarsa, Psikologi Anak dan Remaja (Jakarta: BPK Gunung Mulia, 2002), 37.

${ }^{13}$ Harris Clemes, Mengajarkan Disisplin Kepada Anak (Jakarta: Mitra Utama, 1996), 28. 
Pola pengasuhan yang diberikan oleh pengasuh kepada anak asuhnya bisa dalam bentuk fisik maupun psikis yang tercermin dalam tutur kata, sikap, perilaku dan tindakan yang diberikan. ${ }^{14}$

Jadi pola pengasuhan adalah suatu keseluruhan interaksi antara pengasuh dengan anak asuhnya, dimana pengasuh bermaksud menstimulasi anaknya dengan mengubah tingkah laku, pengetahuan serta nilai-nilai yang dianggap paling tepat oleh pengasuh, agar anak dapat mandiri, tumbuh dan berkembang secara sehat dan optimal. Semua sikap dan perilaku anak ketika berada di Panti asuhan sangat dipengaruhi oleh pola pengasuhan yang dilakukan pengasuh dalam mempengaruhi perkembangan jiwa anak tersebut. Karena mereka berlatar belakang yang berbeda maka sepatutnya para pengasuh harus memilih pola asuh yang ideal untuk mereka, namun dalam pelaksanaanya banyak dari para pengasuh yang masih kaku dan terbatas dalam menerapkan satu pola asuh yang saja dan tidak disesuaikan dengan konteks kebutuhan dan kemampuan yang di miliki anak-anak asuh mereka.

a. Jenis-Jenis Pola Asuh

Jenis-jenis pola asuh secara garis besar menurut Baumrind yang dikutip oleh kartono terdapat 4 macam pola asuh orang tua, yaitu :

1) Pola asuh Demokratis

Pola asuh demokratis adalah pola asuh yang memprioritaskan kepentingan anak, tetapi tidak ragu-ragu dalam mengendalikan mereka. Para pengasuh dengan pola asuh seperti ini bersikap rasional, selalu mendasari tindakannya pada rasio atau pemikiran-pemikiran. Pengasuh tipe ini juga bersikap realistis terhadap kemampuan anak, tidak berharap yang berlebihan yang melampaui kemampuan anak. Pengasuh tipe seperti ini juga meberikan kebebasan pada anak untuk memilih dan melakukan suatu tindakan dan pendekatan kepada anak bersifat hangat.

Menurut Hurlock, pengasuhan demokrasi menerapkan komunikasi dua arah dalam menerapkan aturan. Mereka melihat bahwa anak berhak mengetahui

\footnotetext{
${ }^{14}$ Theo Riyanto, Pembelajaran Sebagai Proses Bimbingan Pribadi (Jakarta: Gramedia, Widiasarana Indonesia, 2002), 89.
} 
260 | MUSAWA, Vol. 11 No. 2 Desember 2019 : 253 - 288

mengapa peraturan ini dibuat, dan mereka diberikan kesempatan untuk mengemukakan pendapat sendiri bila mereka menganggap peraturan tersebut tidak adil, sekalipun anak masih kecil, mereka diberikan penjelasan mengenai peraturan tersebut. Karena pengasuh demokratis tidak mengharapkan anak asuhnya memathi peraturan secara membabi buta. Hukuman tidak pernah keras dan biasanya tidak berbentuk hukuman fisik. ${ }^{15}$

Adapun ciri-ciri pola asuh demokratis adalah sebagai berikut:

a) Menetukan peraturan dan displin dengan memperhatikan dan mempertimbangkan alasan-alasan yang dapat diterima dan dipahami dan dimengrti oleh anak.

b) Memberikan pengarahan tentang perbuatan yang harus di pertahankan oleh anak dan yang tidak baik agar ditinggalkan.

c) Memberikan bimbingan dengan penuh pengertian.

d) Dapat menciptakan keharmonisan pada keluarga di Panti Asuhan.

e) Dapat menciptakan suasana komunikatif antara pengasuh, anak dan sesama keluarga. ${ }^{16}$

\section{2) Pola asuh Otoriter (Authoritatian)}

Manurut kamus bahasa Indonesia, otoriter berati berkuasa sendiri dan sewenang-wenang. ${ }^{17}$ Menurut Singgih D. Gunarsa, pola asuh otoriter adalah suatu bentuk pola yang yang menuntut anak agar patuh dan tuntuk terhadap semua perintah dan aturan yang dibuat oleh pengasuh tanpa ada kebebasan untuk bertanya atau mengemukakan pendapatnya sendiri. ${ }^{18}$

Menurut Hurlock, bahwa orang tua yang otoriter menerapkan peraturan-peraturan dan pemberitahuan kepada anak bahwa ia harus mematuhi peraturan tersebut. Pengasuh tidak berusaha untuk menjelaskan kepada anak kenapa dia harus patuh dan anak tidak diberi kesempatan untuk mengemukakan pendapat tentang adil atau tidaknya peraturan peraturan atau apakah peraturan tersebut masuk akal atau tidak, kalau anak tidak mematuhi aturan, ia akan diberi hukuman. Pengasuh otoriter menganggap bahwa hukuman merupakan

${ }^{15}$ Elizabeth, B. Hurlock. Perkembangan Anak Jilid II, (Jakarta: Erlangga, 1995), 94.

${ }^{16}$ Zahara Idris dan Lisma Jamal, Pengantar Pendidikan (Jakarta: Gramedia, Widiasarana, 2002), 88.

${ }^{17}$ Depdikbud, Kamus Besar Bahasa Indonesia, (Jakarta: Bulan Bintang, 1996), 692.

${ }^{18}$ Singgih D. Gunasa, Psikologi Perkembangan Anak dan Remaja (Jakarta: PT BPK Gunung Mulia, 1995), 87. 
cara efektif untuk mencegah pelanggaran aturan dimasa mendatang. ${ }^{19}$ Pendapat tersebut didukung oleh pendapatnya Barnadib, menurutnya bahwa pengasuh otoriter adalah pengasuh sebagai pemegang peranan. Semua kekuasaan ada padanya, dan semua keaktifan anak ditentukan olehnya. Anak sama sekali tidak mempunyai hak untuk mengemukaan pendapat. ${ }^{20}$

Pola asuh ini cenderung menetapkan standar yang mutlak harus dituruti, biasanya dibarengi dengan ancaman-ancaman. Pengasuh tipe ini cenderung memaksa, memerintah, menghukum. Apabila anak tidak mau melakukan apa yang dikataka oleh pengasuh, maka pengasuh itu tidak segan-segan untuk menghukum anak. Pengasuh seperti ini juga tidak mengenal kompromi dalam komunikasi besifat satu arah . pengasuh seperti ini tidak memerlukan umpan balik dari anak asuhnya untuk memahami dan mengerti anak asuhnya.

Adapun citi-ciri pola asuh otoriter adalah sebagai berikut:

a) Anak harus mematuhi aturan aturan pengasuh dan tidak boleh membantahnya.

b) Pengasuh cenderung mencari kesalahan-kesalahan anak dan kemudian menghukumnya.

c) Pengasuh cenderung memberikan perintah dan larangan kepada anak.

d) Jika terdapat perbedan pendapat antara pengasuh dengan anak, maka anak dianggap pembangkang.

e) Pengasuh cenderung memaksakan disiplin.

f) Pengasuh cenderung memaksakan sesuatu untuk anak dan anak-anak hanya pelaksananya.

g) Tidak adanya komunikasi antara pengasuh dan anak. ${ }^{21}$

3) Pola asuh permisif (permissive)

Pengasuhan Permisif adalah pengasuhan yang memberikan kebebasan penuh kepada anak untuk memilih dan mengatur perilakunya. ${ }^{22}$ Pola pengasuhan ini berbalikan dengan pengasuhan otoriter. Menutur Hurlock pengasuh permitif tidak mengajarkan peraturan kepada anak asuhnya. Anak sering tidak diberi

\footnotetext{
${ }^{19}$ Hurlock, Perkembangan, 93.

${ }^{20}$ Sutari Imam Barnadib, Pengantar Ilmu Pendidikan Sistematis (Yogyakarta: offset,
} 1995), 123.

${ }^{21}$ Zahara Idris dan Lisma Jamal, Pengantar Pendidikan (Jakarta: Gramedia, 1998) 88.

${ }^{22}$ Arini Hidayah, Televisi dan Perkembangan Sosial Anak (Yogyakarta: Pustaka pelajar, 1998), 45. 
262 | MUSA WA, Vol. 11 No. 2 Desember 2019 : 253 - 288

batas-batas atau kendala-kendala yang mengatur apa saja yang boleh dilakukan. mereka diberikan izin untuk mengambil keputusan sendiri. Mereka tidak dihukum jika melanggar, juga tidak diberikan penghargaan ketika mereka berperilaku sosial baik. ${ }^{23}$

Pola ini memberikan pengawasan yang sangat longgar. Memberikan kesempatan pada anak asuh untuk melakukan sesuatu tanpa pengawaan yang cukup darinya. Mereka cenderung tidak menegur atau memperingatkan apabila anak sedang dalam masalah atau bahaya. Dan sangat sedikit bimbingan yang diberikan oleh mereka.

Namun pengasuh tipe ini biasanya hangat, sehingga disukai oleh anak-anak. Adapun yang termasuk pola asuh permisif adalah sebagai berikut:

a) Membiarkan anak bertindak sendiri tanpa memonitor dan membimbingnya.

b) Mendidik anak asuhnya secara acuh tak acuh, bersikap pasif dan masa bodoh.

c) Mengutamakan kebutuhan material saja.

d) Membiarkan saja yang dilakukan anak (terlalu memberikan kebebasan untuk mengatur dirinya sendiri tanpa ada peraturan-peraturan dan norma-norma yang digariskan oleh pengasuh).

e) Kurang sekali keakraban dan hubungan yang hangat dalam keluarga. ${ }^{24}$

M. Thalib menyatakan pengasuh yang permisif yaitu:

a). Kurang tegas dalam menerapkan peraturan.

b). Anak diberikan kebebasan sebebas-bebasnya untuk berbuat dan memenuhi keinginannya. ${ }^{25}$

Pola asuhan permisif ditandai dengan adanya kebebasan tanpa batas pada anak untuk berperilaku sesuai dengan keinginnanya sendiri. Pengasuh tidak memberikan peraturan ataupun mengarahkan anak asuhnya ke jalan yang benar. Anak tidak mengerti apakah perilakunya benar atau salah karena pengasuh tidak pernah membenarkan atau menyalahkan anak, akibatnya anak asuh akan

\footnotetext{
${ }^{23}$ Hurlock, Perkembangan Anak, 93.

${ }^{24}$ Idris dan Lisma Jamal, Pengantar, 89-90.

${ }^{25}$ M. Thalib, 40 Tanggung Jawab Orang Tua Terhadap Anak, (Bandung: Irsyad Baitus Salam, 1995), 7-9.
} 
berperilaku sesuai dengan keinginnanya sendiri, tidak peduli apakah hal itu sesuai dengan norma masyarakat atau tidak. ${ }^{26}$

4) Pola asuh Penelantar

Pengasuh tipe ini pada umumnya memberikan waktu dan biaya yang sangat minim pada anak asuhnya. Waktu banyak digunakan untuk keperluan pribadi mereka, seperti bekerja memberikan biaya yng cukup minim untuk kebutuhan anak. Sehingga selain kurangnya perhatian dan bimbingan pada anak juga tidak diberiak oleh pengasuh. ${ }^{27}$

Pola asuh penelantar memiliki ciri-ciri yang dikemukakan oleh Gunarsah:

1) Pengasuh lebih banyak meluangkan waktu diluar rumah

2) Perhatian pengasuh terhadap perkembangan anak kurang

3) Membiarkan anak asuhnya untuk bergaul terlalu bebas diluar rumah. ${ }^{28}$

Anak merupakan salah satu anugerah yang diberikan Tuhan kepada seseorang. Tanpa anak tidak akan ada tanda kehidupan dalam suatu keluarga.

b. Faktor-faktor yang mempengaruhi pola asuh

Ada beberapa faktor yang mempengaruhi pola asuh orang tua / pengasuh terhadap anak asuhnya, antara lain :

1) Jenis kelamin

Pengasuh cenderung lebih keras terhadap anak wanita dibanding dengan anak laki-laki.

2) Kebudayaan

Latar belakang buadaya menciptakn perbedaan dalam pola pengasuhan anak. Hal ini jga terkait dengan perbedaan peran antara laki-laki dan perempuan didalam suatu kebudayaan masyarakat.

c. Status sosial

Pengasuh yang berlatar pendidikan yang rendah, tingkat ekonomi kelas menengah dan rendah cenderung lebih keras, memaksa dan kurang toleransi dibanding mereka yang dari kelas atas, tetapi mereka lebih konsisten. ${ }^{29}$

\footnotetext{
${ }^{26}$ Danny I. Yatim, Kepribadian Keluarga Narkotika (Jakarta: Arcan, 1991), 97.

${ }^{27}$ Kartini Kartini, Peran Orang Tua Dalam Memandu Anak, (Jakarta: Rajawali, 1992), 39.

${ }^{28}$ Gunarsa, Psikologi, 56.
} 
264 | MUSAWA, Vol. 11 No. 2 Desember 2019 : 253 - 288

\section{Pola asuh anak menurut Zakiah Daradjat}

Menurut Daradjat pembentukan identitas anak menurut Islam, dimulai jauh sebelum anak diciptakan. Islam memberikan berbagai syarat dan ketentuan pembentukan keluarga, sebagai wadah yang akan mendidik anak sampai umur tertentu yang disebut sebagai baligh berakal. ${ }^{30}$

Dengan demikian, dapat dipahami bahwa pembinaan kepribadian anak telah mulai dalam keluarga sejak ia lahir, bahkan sejak dalam kandungan. Kepribadian yang masih dalam permulaan pertumbuhan sangat peka dan mendapatkan unsure pembinanya melalui pengalaman yang dirasakan, baik melalui pendengaran, penglihatan, perasaan dan perlakuan yang diterimanya.

Anak masih belum mampu menilai baik dan buruk, bahkan belum dapat mengerti tentang apa yang dimaksud dengan kata baik dan kata buruk, apalagi kata-kata lain di luar jangkauan pengalamannya secara nyata. Karena kecerdasannya masih dalam permulaan pertumbuhan, belum dapat berpikir logis dan abstrak, pada umur tujuh tahun barulah mulai pertumbuhan pemikiran logis pada anak. Anak adalah masa pertumbuhan manusia sejak usia 0-12 tahun.

Masa usia dapat dibagi dua, yaitu masa usia anak awal atau pra sekolah yaitu sejak usia 0 sampai 6 tahun dan masa usia anak akhir adalah masa Sekolah Dasar yaitu sejak usia 6 sampai 12 tahun. ${ }^{31}$

Sejumlah upaya dilakukan orang tua untuk mendukung pendidikan anakanaknya. Misalnya, dengan menciptakan lingkungan belajar yang kondusif di rumah, penerapan waktu khusus belajar bagi anak dan melakukan pendampingan saat anak belajar, bahkan tak sedikit pula orang tua yang mengalokasikan anggaran khusus untuk les tambahan yang diharapkan bisa meningkatkan prestasi anak di sekolah. Apapun upaya yang dilakukan itikadnya satu, yaitu peduli pada pendidikan anak.

Orang tua di dalam kehidupan keluarga mempunyai posisi sebagai kepala keluarga atau pemimpin rumah tangga, orang tua sebagai pembentuk pribadi

\footnotetext{
${ }^{29}$ Ibid.,

${ }^{30}$ Zakiah Daradjat, Pendidikan Islam Dalam Keluarga dan Sekolah Cet. II (Jakarta: CV.

${ }^{31}$ Zakiah Daradjat, Ilmu Jiwa Agama Cet. XVII (Jakarta: Bulan Bintang, 2009), 69.
} Ruhama, 1995), 41. 
pertama dalam kehidupan anak, kepribadian orang tua, sikap dan cara hidup mereka merupakan unsur-unsur pendidikan yang tidak langsung, yang dengan sendirinya akan masuk ke dalam pribadi anak yang sedang tumbuh.

Menurut Daradjat, sesungguhnya yang terpenting dalam pendidikan anak adalah keseluruhan perlakuan-perlakuan yang diterima oleh si anak dari orang tuanya, di mana ia merasa disayangi, diperhatikan dan diindahkan dalam keluarga. Di samping itu ia harus merasa bahwa dalam hubungannya dengan orang tua, diperlakukan adil di antara saudara-saudaranya, ia merasa aman dan tentram, tanpa rasa ketakutan akan dimarahi, diolok atau dibanding-bandingkan dengan saudara-saudaranya yang lain. Kebebasan dalam batas-batas kewajaran tidak terlalu terikat atau dikekang oleh peraturan-peraturan atau nasehat orang tua. ${ }^{32}$

Apa yang diuraikan Daradjat, tampaknya tidak jauh dengan fenomena di masyarakat, karena dalam kenyataannya ada bapak yang terlalu keras dan mengekang si anak dalam segala gerak-geriknya. Ia menuntut kapatuhan dari anak-anaknya, dengan cara menakut-nakuti atau mengancam, tanpa memperhatikan perasaan dan kebutuhan si anak. Bapak yang seperti ini dianggap tidak wajar. Tidak jarang anak-anaknya menjauh dan tidak mau mematuhinya, hal tersebut dapat berakibat kepada semangat belajar si anak, kadang-kadang ia gagal dalam belajar.

Menurut Daradjat, membina pendidikan anak, harus dimulai sejak si anak lahir, sebagaimana diajarkan oleh agama Islam, yang memerintahkan supaya, setiap bayi lahir harus diazankan, demi supaya pengalaman pertama yang diterimanya, adalah kalimah suci yang membawa kepada takwa. Penanaman. jiwa takwa, perlu dilakukan, yaitu takwa seperti yang disebutkan dalam surat alBaqarah ayat 177., yang mana ditegaskan bahwa takwa itu adalah: (a) iman kepada Allah SWT., Hari Kemudian, Malaikat, Kitab-kitab dan Nabi-nabi; (b) memberikan harta yang dicintai kepada kaum kerabat, anak yatim, orang miskin, musafir yang kekurangan, orang minta-minta dan memerdekakan budak; (c)

\footnotetext{
${ }^{32}$ Zakiah Daradjat, Kesehatan Mental Cet. 10 (Jakarta: GunungAgung, 1993), 27.
} 
266 | MUSA WA, Vol. 11 No. 2 Desember 2019 : 253 - 288

mendirikan shalat; (d) mengeluarkan zakat; (e) menepati janji yang telah dibuat; dan (f) sabar dalam kesempitan penderitaan dan peperangan. ${ }^{33}$

Membina agama anak, itu harus sejak si anak masih kecil, yang dalam hal ini pada usia-usia permulaan ditanamkan dengan contoh-contoh dan latihan yang terus- menerus dan tetap, yang dilakukan dengan lemah lembut, jauh dari kekerasan dan paksaan; sesuai dengan pertumbuhan si anak dari segi psikis. Jiwa takwa inilah yang akan menjadi pengendali dalam kehidupan anak di kemudian hari, hendaklah sesuai dengan perkembangan dan cita-cita khas usia si anak.

Setiap orang tua pasti menginginkan anaknya menjadi orang yang berkepribadian baik, sikap mental yang sehat serta akhlak yang terpuji. Orang tua sebagai pembentuk pribadi yang pertama dalam kehidupan anak, dan harus menjadi teladan yang baik bagi anak-anaknya. Menurut Daradjat bahwa, "kepribadian orang tua, sikap dan cara hidup merupakan unsur-unsur pendidikan yang secara tidak langsung akan masuk ke dalam pribadi anak yang sedang tumbuh."Memilih cara yang tepat dalam mendidik anak adalah hal yang harus ditekankan pada seorang pendidik khususnya orang tua, karena orang tua merupakan pendidik utama di dalam keluarga sejak anak terlahir di dunia. ${ }^{34}$

Daradjat memberikan cara pola asuh yang ditawarkan kepada orang tua/pendidik yaitu tidak mendidiknya dengan kebebasan yang sangat atau toleransi yang berlebih-lebihan. Karena, jika terlalu bebas akan menjadi pengaruh yang tidak baik bagi pertumbuhan anak. Tetapi juga sebaliknya, jangan terlalu menekan, keras, banyak perintah, larangan, teguran dan tidak mengindahkan keinginan anak, yang menyebabkan ketegangan terhadap anak. Banyak orang tua yang menyangka bahwa kekerasan dalam mendidik anak itu baik, dan perlu agar anak nanti bisa hidup sebagaimana mestinya. ${ }^{35}$ Daradjat menegaskan kembali dengan mengingatkan kepada pendidik khususnya orang tua, bahwa kekerasan dalam pendidikan tetap tidak baik, bagaimanapun juga kelakuan

\footnotetext{
${ }^{33}$ Ibid.,

${ }^{34}$ Ibid.,

${ }^{35}$ Ibid.,
} 
si anak. Karena, hal tersebut malah bertambahnya kelakuan buruk dan gangguan psikologi si anak.

\section{HASIL DAN PEMBAHASAN}

Peranan suami dan isteri dalam keluarga selanjutnya disebut Orang tua terdiri dari ayah, ibu serta saudara adik dan kakak. Orang tua atau biasa disebut juga dengan keluarga, atau yang identik dengan orang yang membimbing anak dalam lingkungan keluarga. Meskipun orang tua pada dasarnya dibagi menjadi tiga, yaitu orang tua kandung, orang tua asuh, dan orang tua tiri. Tetapi yang kesemuanya itu dalam bab ini diartikan sebagai keluarga. Sedangkan pengertian keluarga adalah suatu ikatan laki-laki dengan perempuan berdasarkan hukum dan undang-undang perkawinan yang sah. ${ }^{36}$

Orang tua adalah orang yang mempunyai amanat dari Allah untuk mendidik anak dengan penuh tanggungjawab dan dengan kasih sayang. Orang tua (keluarga) yang bertanggung jawab yang paling utama atas perkembangan dan kemajuan anak. Orang tua adalah komponen keluarga yang terdiri dari ayah dan ibu, dan merupakan hasil dari sebuah ikatan perkawinan yang sah yang dapat membentuk sebuah keluarga. Orang tua memiliki tanggung jawab untuk mendidik, mengasuh dan membimbing anak-anaknya untuk mencapai tahapan tertentu yang menghantarkan anak untuk siap dalam kehidupan bermasyarakat.

Sedangkan pengertian orang tua di atas, tidak terlepas dari pengertian keluarga, karena orang tua merupakan bagian keluarga besar yang sebagian besar telah tergantikan oleh keluarga inti yang terdiri dari ayah, ibu dan anakanak. ${ }^{37}$

Menurut Hendi keluarga diartikan sebagai suatu kelompok yang terdiri dari dua orang atau lebih yang dihubungkan dengan pertalian darah,perkawinan atau adopsi (hukum) yang memiliki tempat tinggal bersama.

\footnotetext{
${ }^{36}$ Mansur, Pendidikan Anak Usia Dini dalam Islam (Yogyakarta: Pustaka Pelajar, 2005), 318.

${ }^{37}$ Hendi dan Rahmadani Wahyu Suhendi, Pengantar Studi Sosiolog Keluarga, (Bandung: CV Pustaka Setia, 2000), 41.
} 
268 | MUSA WA, Vol. 11 No. 2 Desember 2019 : 253 - 288

Selanjutnya, Abu Ahmadi dalam Hendi mengenai fungsi keluarga adalah sebagai suatu pekerjaan atau tugas yang harus dilakukan di dalam atau diluar keluarga. ${ }^{38}$

Menurut Badan Penasehat Perkawinan Perselisihan dan Perceraian, dalam Ahmadi keluarga adalah masyarakat yang terkecil sekurang-kurangnya terdiri dari pasangan suami atau istri sebagai intinya berikut anak-anak yang lahir dari mereka. Unit terkecil dalam masyarakat yang terdiri dari dua orang lebih tinggal bersama karena ikatan perkawinan atau darah, terdiri dari ayah, ibu, dan anak. ${ }^{39}$ Menurut pandangan sosiologi, keluarga dalam arti luas meliputi semua pihak yang mempunyai hubungan darah dan atau keturunan, sedangkan dalam arti sempit keluarga meliputi orang tua dengan anak- anaknya. ${ }^{40}$

Ada beberapa pandangan, keluarga adalah lembaga sosial resmi yang terbentuk setelah adanya perkawinan. Menurut Undang-undang perkawinan Nomor 1 Tahun 1974 pasal 1, menjelaskan bahwa:

Perkawinan adalah ikatan lahir batin antara seorang pria dan seorang wanita sebagai suami isteri dengan tujuan membentuk keluarga yang bahagia dan sejahtera berdasarkan Ketuhanan Yang Maha Esa. ${ }^{41}$

Anggota keluarga terdiri dari suami, isteri atau orang tua (ayah dan ibu) serta anak. Ikatan dalam keluarga tersebut didasarkan kepada cinta kasih sayang antara suami istri yang melahirkan anak-anak. Oleh karena itu hubungan pendidikan dalam keluarga adalah didasarkan atas adanya hubungan kodrati antara orang tua dan anak. Pendidikan dalam keluarga dilaksanakan atas dasar cinta kasih sayang yang kodrati, rasa kasih sayang yang murni, yaitu rasa cinta kasih sayang orang tua terhadap anaknya.

Rasa kasih sayang inilah yang menjadi sumber kekuatan menjadi pendorong orang tua untuk tidak jemu-jemunya membimbing dan memberikan pertolongan yang dibutuhkan anak-anaknya. Sebagaimana Firman Allah Swt dalam QS. Al-A'raf [7]: 173 berikut ini:

\footnotetext{
${ }^{38} \mathrm{Ibid}, 44$.

${ }^{39}$ Abu Ahmadi, Ilmu Sosial Dasar (Jakarta: PT Rineka Cipta, 1991), 104.

${ }^{40}$ Jalaluddin Rakhmat, Keluarga Muslim Dalam Masyarakat Modern, (Bandung: PT. Remaja Rosdakarya, 1994), 20.

${ }^{41}$ Undang-undang perkawinan Nomor 1 Tahun 1974 pasal 1.
} 


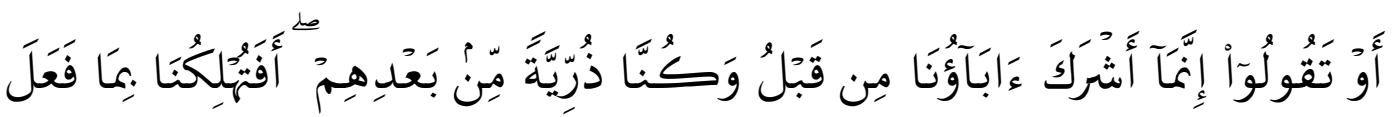

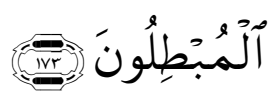

Terjemahnya:

Atau agar kamu tidak mengatakan:Sesungguhnya orang-orang tua kami telah mempersekutukan Tuhan sejak dahulu, sedang kami ini adalah anakanak keturunan yang (datang) sesudah mereka. Maka apakah Engkau akan membinasakan kami karena perbuatan orang-orang yang sesat dahulu? ${ }^{42}$

Keluarga adalah merupakan kelompok primer yang paling penting didalam masyarakat. Keluarga merupakan sebuah grup yang terbentuk dari perhubungan laki-laki dan wanita, perhubungan mana sedikit banyak berlangsung lama untuk menciptakan dan membesarkan anak-anak. Jadi keluarga dalam bentuk yang murni merupakan satu-kesatuan sosial ini mempunyai sifat-sifat tertentu yang sama, dimana saja dalam satuan masyarakat manusia.

Menjadi ayah dan ibu tidak hanya cukup dengan melahirkan anak, kedua orang tua dikatakan memiliki kelayakan menjadi ayah dan ibu manakala mereka bersungguh-sungguh dalam mendidik anak mereka. Islam menganggap pendidikan sebagai salah satu hak anak, yang jika kedua orang tua melalaikannya berarti mereka telah menzalimi anaknya dan kelak pada hari kiamat mereka dimintai pertanggung jawabannya. Rasulullah Saw bersabda:

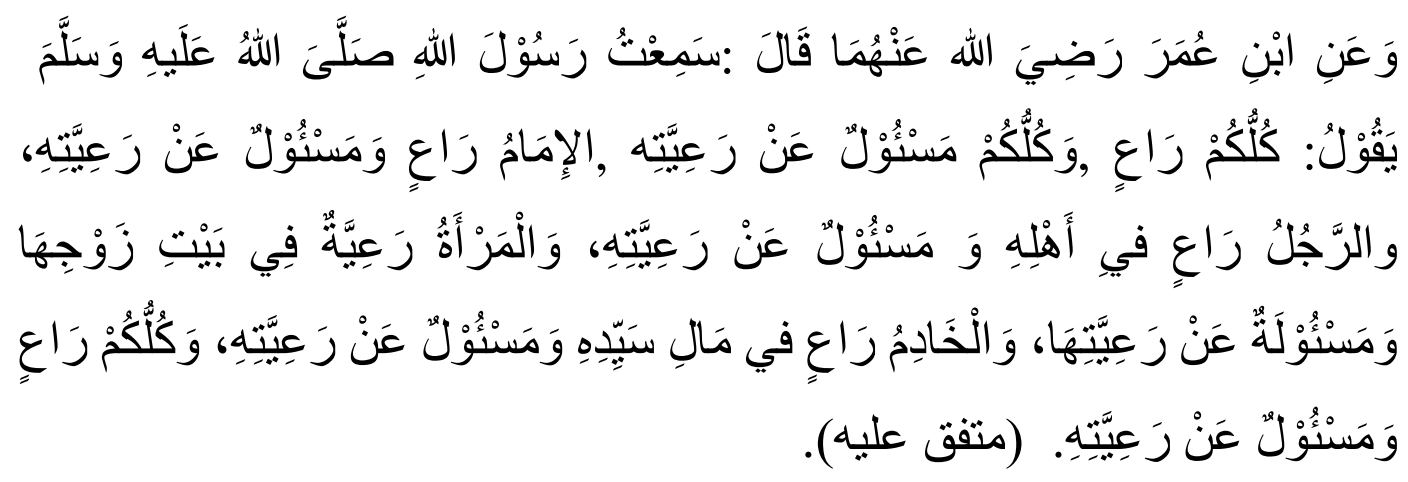

Artinya:

'Dari Umar ra berkata: aku pernah mendengar Rasulullah saw bersabda: Kamu semua adalah pemimpin dan kamu semua bertanggung jawab atas rakyat yang dipimpinnya, imam adalah pemimpin dan akan

${ }^{42}$ Departemen Agama RI, Al-Qur'an dan Terjemahnya Edsisi Ilmu Pengetahuan (Bandung: Mizan Pustaka, 2009): 174. 
270 | MUSAWA, Vol. 11 No. 2 Desember 2019 : 253 - 288

ditanya tentang yrakyat yang dipimpinnya, laki-laki (suami) adalah pemimpin bagi keluarganya dan akan ditanya tentang keluarga yang dipimpinnya, wanita (istri) adalah pemimpin dirumah suaminya dan ia akan ditanya tentang keluarga yang dipimpinnya, pembantu adalah pemimpin atas harta kekayaan majikannya dan ia akan ditanya tentang kepemimpinannya dan kamu semua adalah pemimpin dan bertanggung jawab atas yang dipimpinnnya."(HR: Bukhari-muslim). ${ }^{43}$

\section{Penjelasan Hadits.}

Kepemimpinan adalah amanat, sedang amanat yang disia-siakan konsekuensinnya tidak ringan. Maka seorang pemimpin yang tidak menunaikan amanat kepemimpinannya terhadap umat yang dipimpinnya, seperti menipu mereka dan sebagainya maka ancamannya sangat berat, yaitu dijauhkan dari rahmat Allah swt di akhirat nanti sehingga haram baginya surga. ${ }^{44}$

Kemudian diantara tugas seorang pemimpin terhadap rakyat yang dipimpinnya ialah, membimbing, mengarahkan, dan menunjukan jalan-jalan kebajikan terhadap mereka dengan nasihat-nasihat yang baik. Jadi pada dasarnya seorang pemimpin haruslah bersungguh-sungguh dalam berkhidmat kepada rakyat yang dipimpinnya serta menunaikan kewajiban-kewajibannya. Kalau beban dan tugas ini tidak ditunaikan, maka kelak diakhirat nanti tidak ada lain balasannya kecuali api neraka. ${ }^{45}$

\section{Pelajaran dari Hadis.}

a. Anjuran terhadap pemimpin untuk menunaikan kewajiban-kewajibannya dalam memimpin rakyatnya.

b. Pemimpin yang mengabaikan amanat kepemimpinannya kelak akan dibalas dengan siksa keras di akhirat nanti. ${ }^{46}$

Orang tua atau ibu dan ayah memegang peranan yang penting dan amat berpengaruh atas pendidikan anak-anaknya. Pendidikan orang tua terhadap anak anaknya adalah pendidikan yang didasarkan pada rasa kasih sayang terhadap anak-anak, dan yang diterimanya dari kodrat. Orang tua adalah pendidik

\footnotetext{
${ }^{43}$ Husaini A. Majid Hasyim, Syarah: Riyadus Shalihin. Diterjemahkan Oleh: Mu'ammal Hamidi dan Imron A. Manan (Surabaya: PT. Bina Ilmu, 1993), 1.

${ }^{44}$ Ibid, 3.

${ }^{45}$ Ibid.,

${ }^{46}$ Ibid.,
} 
sejati, pendidik karena kodratnya. Oleh karena itu, kasih sayang orang tua terhadap anak-anak hendaklah kasih sayang yang sejati pula. ${ }^{47}$

Dari penjelasan diatas dapat disimpulkan bahwa yang dimaksud dengan keluarga adalah kesatuan unsur terkecil yang terdiri dari bapak, ibu dan beberapa anak. Masing-masing unsur tersebut mempunyai peranan penting dalam membina dan menegakkan keluarga, sehingga bila salah satu unsur tersebut hilang maka keluarga tersebut akan guncang atau kurang seimbang.

Peran tugas dan fungsi orang tua secara alamiah dan kodratnya harus melindungi dan menghidupi serta mendidik anaknya agar dapat hidup dengan layak dan mandiri setelah menjadi dewasa. Oleh karena itu tidak cukup hanya memberi makan minum dan pakaian saja kepada anak-anakya saja tetapi harus berusaha agar anaknya menjadi baik, pandai dan berguna bagi kehidupannya dimasyarakat kelak. Orang tua dituntut mengembangkan potensi yang dimiliki anaknya agar secara jasmani dan rohani dapat berkembang dengan selaras dan seimbang secara maksimal.

Tugas dan tanggung jawab tersebut tidaklah mudah terutama dalam mendidik anak. Minimnya pendidikan kepribadian, mental dan perhatian orang tua akibatnya dapat terbawa arus hal-hal negativ seperti penyalah gunaan obatobat terlarang yang saat ini sedang berkembang dikota besar bahkan sampai kekampung-kampung yang akinbatnya akan merusak mental dan masa depan anak, khususnya para pelajar yang diharapkan untuk menjadi generasi penerus bangsa yang sangat potensial dan produktif. Tanggung jawab pendidikan yang perlu disadarkan dan dibina oleh kedua orang tua terhadap anak. Fuad Ihsan mengungkapkan sebagai berikut:

a. Memelihara dan membesarkanya. Tanggung jawab ini merupakan dorongan alami yang dilaksanakan, karena akan memerlukan makan. Minum dan perawatan agar ia dapat hidup secara berkelanjutan.

b. Melindungi dan menjamin kesehatannya, baik secara jasmaniah maupun rohaniah dari berbagai penyakit atau bahaya lingkungan yang dapat membahayakan dirinya. ${ }^{48}$

\footnotetext{
${ }^{47}$ Ibid.,

${ }^{48}$ Fuad Ihsan . Dasar-dasar Kependidikan (Jakarta: PT. Rineka Cipta, 2008), 52.
} 
272 | MUSA WA, Vol. 11 No. 2 Desember 2019 : 253 - 288

Islam sangat menekankan kepada orang tua untuk berkewajiban mengasuh merawat, menjaga dan melindungi anak. Atas dasar bahwa anak adalah titipan (amanah) Allah Swt yang harus dijaga baik-baik, sebab mereka akan mempertanggungjawabkannya kepada Allah Swt. Anak selama bertahun-tahun pada permulaan hidupnya belum dapat menyadari terhadap bahaya yang mengancam hidupnya. Di samping itu juga mereka belum dapat menjaga dan menghindarkan diri dari mara bahaya dan ancaman berbagai penyakit, oleh karena itu orang tuanyalah yang bertangung jawab terhadap tumbuh kembang anaknya. Sebagaimana Firman Allah Swt dalam QS. At-Tharim [66]: 6

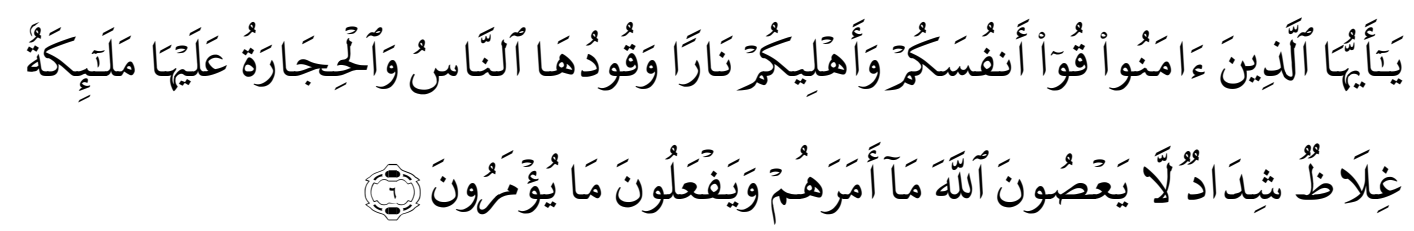

Terjemahnya:

Hai orang-orang yang beriman, perliharalah dirimu dan keluargamu dari api neraka yang bahan bakarnya adalah manusia dan batu; penjaganya malaikat-malaikat yang kasar, yang keras, yang tidak mendurhakai Allah terhadap apa yang diperintahkan-Nya kepada mereka dan selalu mengerjakan apa yang diperintahkan". ${ }^{49}$

Pada ayat ini orang tua diperintahkan Allah SWT untuk memelihara keluarganya dari api neraka, dengan berusaha agar seluruh anggota keluarganya itu melaksanakan perintah-perintah dan larangan-larangan Allah, termasuk anggota keluarga dalam ayat ini adalah anak. Allah SWT. menjelaskan bahwa Allah tidak menuntut manusia untuk bersih tanpa kesalahan, melainkan meminta mereka untuk kembali kepada jalan yang benar jika melakukan kesalahan, kembali kepada Tuhan mereka, mengambil pelajaran dari berbagai pengalaman agar dapat berjalan dengan benar dan menjaga mereka dari keterpelesetan. ${ }^{50}$

Dalam ayat lain Allah Swt berfirman dalam QS. Lukman [31]: 14 berikut ini:

${ }^{49}$ Departemen Agama RI, Al-Qur'an, 561.

${ }^{50}$ Syeikh Muhammad Ghazali, Tafsir Tematik: Dalam Al-Qur'an (Jakarta: Gaya Media Pratama, 2004), 589. 


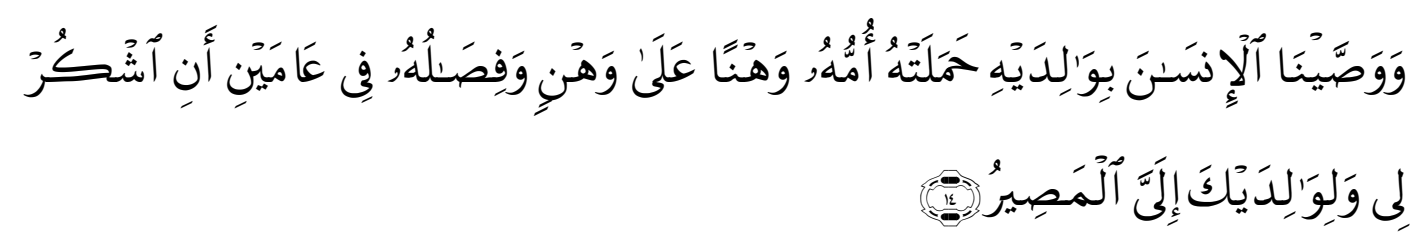

Terjemahnya;

Dan Kami perintahkan kepada manusia (berbuat baik) kepada dua orang ibu- bapanya; ibunya telah mengandungnya dalam Keadaan lemah yang bertambah- tambah, dan menyapihnya dalam dua tahun. bersyukurlah kepadaku dan kepada dua orang ibu bapakmu, hanya kepada-Kulah kembalimu. ${ }^{51}$

Menurut sebagian para ulama, ayat diatas bukanlah bagian pengajaran Lukman kepada anaknya. Ia disisipkan Al-qur'an untuk menunjukkan betapa penghormatan dan kebaktian kepada kedua orang tua yang menempati posisi kedua setelah pengagungan kepada Allah Swt. ${ }^{52}$ Dan kita diperintahkan untuk berbakti kepada kedua orang tua, sebagaimana dalam Q.S. Al-an'am [6]: 151 yang menyatakan: "katakanlah (Muhammad), marilah aku bacakan apa yang diharamkan tuhan kepadamu. Janganlah memprsekutukan-Nya dengan apa pun, berbuat baik kepada ibu bapak......dan seterusnya". Ayat diatas memerintahkan kita untuk berbuat baik kepada kedua orang tua dan jangan sekali-kali kita mengucapkan kata "ah" pada keduanya, sebagaimana dalam qur'an surah Alisra'[17]: 23.

Kata (ووصينا) wawassayna. Yaitu berpesan dengan sangat kukuh kepada manusia menyangkut kedua orang tua mereka, agar selalu berbuat baik kepada keduanya. Kata (وهنا) wahnan yaitu kelemahan yang dirasakan oleh seorang ibu untuk memikul beban kandungan yang kian memberat sesuai dengan usia kandungan. Maka untuk itulah kita diperintahkan untuk berbuat baik kepada mereka, dan bersyukur kepada Allah yang menciptakan kita melalui perantara keduanya dan bersyukur pula kepada kedua orang tua yang senantiasa melimpahkan kasih sayangnya kepada kita sebagai seorang anak. ${ }^{53}$ Nilai

\footnotetext{
${ }^{51}$ Departemen Agama RI, Al-Qur'an, 411.

${ }^{52}$ M. Quraish Shihab, Tafsir Al-Misbah, Pesan Kesan dan Keserasian Al-Qur'an (Jakarta: Lentera Hati, 2002), Volume II, 128.

${ }^{53}$ Ibid, 129.
} 
pendidikan yang harus kita ambil yaitu bagaimana cara untuk mempergauli kedua orang tua baik mereka sudah lanjut usia yang dalam pemeliharaan kita

Dalam ayat lain Allah Swt berfirman dalam QS. Al-Baqarah [2]: 233

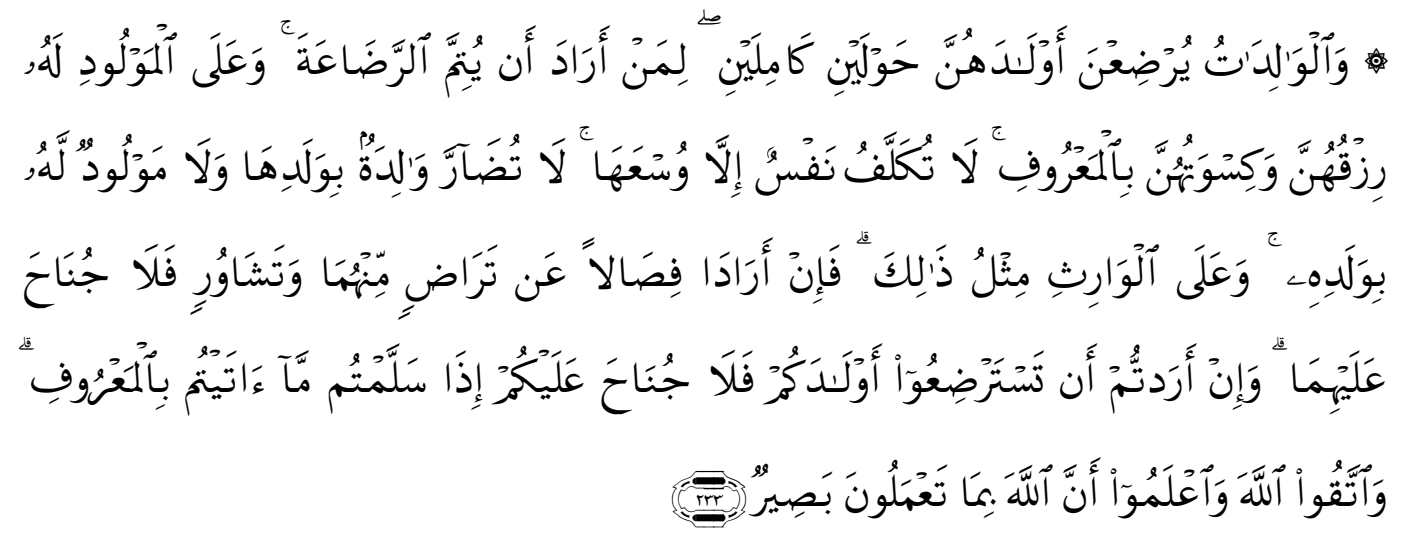

Terjemahnya:

Para ibu hendaklah menyusukan anak-anaknya selama dua tahun penuh, yaitu bagi yang ingin menyempurnakan penyusuan. Dan kewajiban ayah memberi makan dan pakaian kepada para ibu dengan cara ma'ruf. Seseorang tidak dibebani melainkan menurut kadar kesanggupannya. Janganlah seorang ibu menderita kesengsaraan karena anaknya dan seorang ayah karena anaknya, dan warispun berkewajiban demikian. Apabila keduanya ingin menyapih (sebelum dua tahun) dengan kerelaan keduanya dan permusyawaratan, maka tidak ada dosa atas keduanya. Dan jika kamu ingin anakmu disusukan oleh orang lain, maka tidak ada dosa bagimu apabila kamu memberikan pembayaran menurut yang patut. Bertakwalah kamu kepada Allah dan ketahuilah bahwa Allah Maha Melihat apa yang kamu kerjakan. ${ }^{54}$

Ayat ini merupakan rangkaian pembicaraan tentang keluarga, kini pembicaraan tentang anak yang lahir dari hubungan suami istri. Yakni mereka yang memiliki bayi atau anak. Dengan menggunakan redaksi berita, ayat ini memerintahkan dengan sangat tegas kepada para ibu agar menyusukan anak-anaknya, selama sejak kelahiran hingga dua tahun penuh, para ibu diperintahkan untuk menyusukan anak-anak. Dua tahun adalah batasan maksimal dari kesempurnaan penyusuan.

Kata Al-Walidat dalam penggunaan Al-Qur'an berbeda dengan kata ummahbat yang merupakan bentuk jamak dari kata umm. Kata ummahat digunakan untuk menunjuk kepada para ibu kandung, sedang kata Al- Walidat

${ }^{54}$ Departemen Agama RI, Al-Qur'an, 38. 
maknanya adalah: para ibu, baik ibu kandung maupun bukan. Ini berarti bahwa Al-Qur'an sejak dini telah menggariskan bahwa air susu ibu baik ibu kandung maupun bukan, adalah makanan terbaik buat bayi hingga usia 2 tahun. Namun demikian, tentunya air susu ibu kandung lebih baik dari selainnya. Dengan menyusu kepada ibu kandung, anak merasa lebih tenteram; sebab menurut penelitian ilmuan, ketika itu bayi mendengar suara detak jantung ibu yang telah dikenalnya secara khusus sejak dalam perut. Detak jantung ibu berbeda antara seorang wanita dengan wanita yang lain. ${ }^{55}$ Dalam firman Allah Swt dalam QS. Luqman [31]: 17 berikut ini:

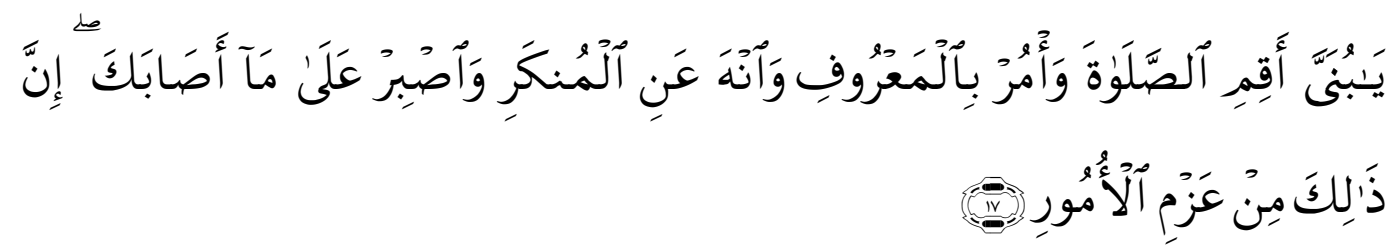

Terjemahnya:

"Wahai anakku, dirikanlah shalat dan suruhlah (manusia) mengerjakan yang baik dan cegahlah (mereka) dari perbuatan yang mungkar dan bersabarlah terhadap apa yang menimpa kamu. Sesungguhnya yang demikian itu termasuk hal-hal yang diwajibkan (oleh Allah), ${ }^{56}$

Salah satu tugas orang tua kepada anaknya ialah mengajarkan untuk menegakkan shalat. Kita harus segera memulai pembersihan batin dengan menjauhi syirik dan melakukan perbaikan spiritual dengan menegakkan shalat, kewajiban amar makruf nahi mungkar tidak hanya ada pada masa Islam (pada zaman Nabi Muhammad Saw), sebelum era Islam yang dikumandangkan oleh Nabi Muhammad Saw, pada masa Luqman juga telah dijelaskan oleh Allah Swt tentang shalat dan amar makruf nahi mungkar. Kita berkewajiban untuk membina anak-anak kita menjadi individu-individu yang bertanggung jawab dan memiliki kepekaan sosial melalui pengasuhan keberimanan, kebertuhanan, menegakkan shalat dan melalui pendidikan amar makruf nahi mungkar. ${ }^{57}$ Dalam pengasuhan anak sudah barang tentu ada hal-hal yang wajib dilaksanakan orang tua, dan ini

${ }^{13}$ M. Quraish Shihab, Tafsir Al-Mishbah: Pesan, Kesan Dan Keserasian Al-Qur'an (Jakarta: Lentera Hati, 2002), 503-504.

${ }^{56}$ Departemen Agama RI, Al-Qur'an, 413.

${ }^{57}$ Seri Dan Mohsen Qaraati, Tafsir Untuk Anak Muda (Jakarta: Al-Huda, 2005), 77-81. 
276 | MUSA WA, Vol. 11 No. 2 Desember 2019 : 253 - 288

menjadi suatu tanggung jawab yang di emban orang tua dalam pengasuhan anak. Kewajiban orang tua dalam pengasuhan anak adalah:

\section{Kewajiban Memberikan Nafkah}

Nafkah merupakan hal yang wajib dipenuhi seorang ayah (suami) untuk keperluan rumah tangga. Harta terbaik adalah harta yang diberikan kepada keluarganya sebagai nafkah, dan seseorang telah di aggap melakukan dosa jika tidak memberi nafkah pada orang-orang yang menjadi tanggungannya. ${ }^{58}$ Nafkah adalah semua kebutuhan dan keperluan yang berlaku menurut keadaan dan tempat, seperti makanan, pakaian, rumah dan lain-lain.

Nafkah merupakan hal yang wajib dipenuhi seorang ayah (suami) untuk keperluan rumah tangga. Harta terbaik adalah harta yang diberikan kepada keluarganya sebagai nafkah, dan seseorang telah diaggap melakukan dosa jika tidak memberi nafkah pada orang-orang yang menjadi tanggungannya. Nafkah bagi anak-anak seperti pahala sedekah. Bertangung jawab dan berkerja untuk mereka sebagai jalan yang aman kesurga dan derajat utama.

Dalam mencari dan memberi nafkah kepada keluarga, seorang ayah haruslah memperhatikan kehalalannya. Karena ini akan sangat berpengaruh terhadap tumbuh kembang jiwa dan ahklak anak, apabila seorang anak dibiasakan dengan uang dan makanan haram, maka iblis telah hidup dalam diri si anak melalui makanan yang haram tersebut. Jadi sudah sepatutnya seorang ayah sangat berhati-hati dalam urusan mencari nafkah. Sebagaimana firman Allah Swt dalam QS. Al-Baqarah [2]: 188 berikut ini:

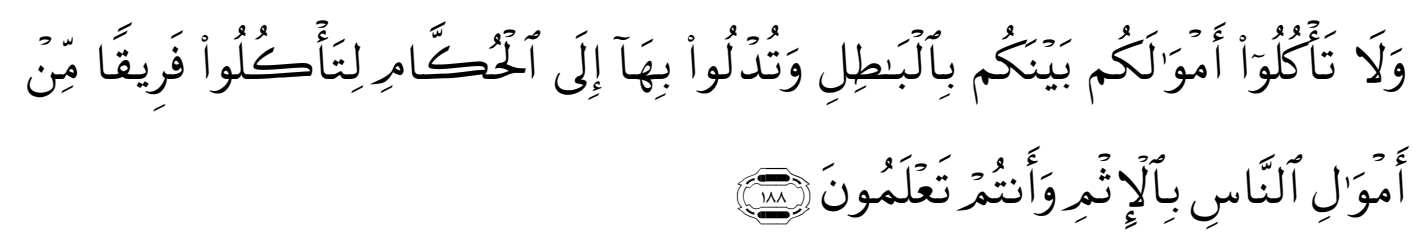

Terjemahnya:

Dan janganlah sebahagian kamu memakan harta sebahagian yang lain di antara kamu dengan jalan yang batil dan (janganlah) kamu membawak (urusan) harta itu kepada hakim, supaya kamu dapat

${ }^{58}$ Lubis Salam, Menuju Keluarga Sakinah Mawaddah dan Warahmah (Surabaya: Terbit Terang, 2007), 93. 
memakan sebahagian daripada harta benda orang lain itu dengan (jalan berbuat) dosa, padahal kamu mengetahui. ${ }^{59}$

Selain memperhatikan kehalalan nafkah dan makanan yang dia berikan kepada keluarganya, Seorang ayah juga tidak boleh berkeluh kesah dalam mencari nafkah karena Allah juga menanggung riski setiap hambanya. Seorang ayah harus bersikap bijak dalam memberikan nafkah. Dia tidak boleh kikir atau pun terlalu berlebihan. Apabila Allah melapangkan riskinya maka ia harus melapangkan belanja untuk keluarganya. Selain itu seorang ayah juga harus mengawasi uang yang diberikan kepada anak dan juga harus bisa dengan bijak membedakan kebutuhan anak yang satu dengan yang lain sesuai dengan kebutuhan anak itu masing-masing. ${ }^{60}$ Sebagaimana hadis rasulullah Saw:

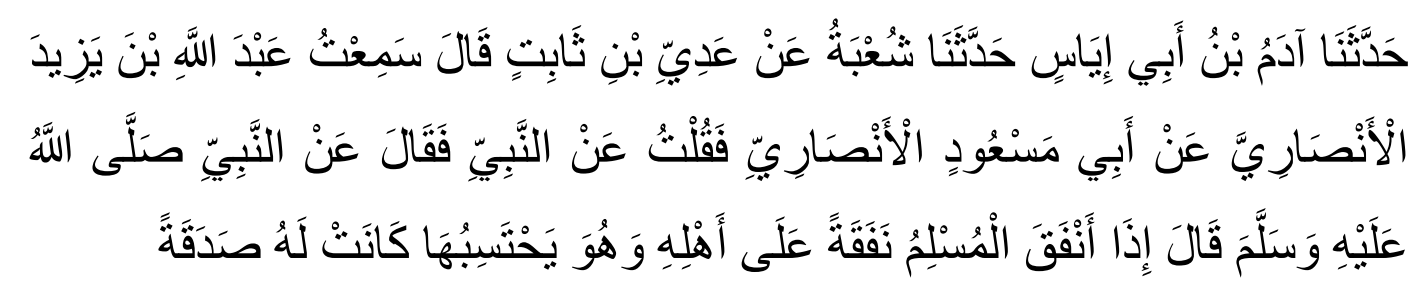

Artinya:

Telah menceritakan kepada kami Adam bin Abu Iyas Telah menceritakan kepada kami Syu'bah dari Adi bin Tsabit ia berkata; Aku mendengar Abdullah bin Yazid Al Anshari dari Abu Mas'ud Al Anshari maka aku berkata; Dari Nabi shallallahu 'alaihi wasallam, beliau bersabda: "Jika seorang muslim memberi nafkah pada keluarganya dengan niat mengharap pahala, maka baginya hal itu adalah sedekah. ${ }^{\prime 161}$

Sesunguhnya Allah suka kepada hambanya yang selalu membagikan nikmat yang telah dikaruniakan kepadanya. Infak kepada anak, keluarga, pelayan, merupakan sedekah apabila dilakukan dengan niat yang ikhlas. Memberi harta dan tempat tinggal kepada anak lebih utama dibandingkan menyedekahkan

\footnotetext{
${ }^{59}$ Departemen Agama RI, Al-Qur'an, 30.

${ }^{60}$ Salam, Menuju, 112-113.

${ }^{61}$ Muhammad Nashiruddin Al-Albani, Ringkasan Shahih Bukhari Jilid 4 (Jakarta: Pustaka Azzam, 2007), 863.
} 
278 | MUSA WA, Vol. 11 No. 2 Desember 2019 : 253 - 288

seluruh hartanya kepada orang lain sementara anaknya dibiarkan terlantar dan meminta belas kasihan orang lain. ${ }^{62}$

2. Kewajiban Menjaga, Merawat, Melindungi Serta Mendidik Anak (Melakukan Hadhanah).

Seorang anak pada permulaan hidupnya sampai pada umur tertentu memerlukan orang lain dalam hidupnya, baik dalam merawat tumbuh kembang fisiknya juga membentuk tumbuh kembang mental dan jiwanya, jadi sudah menjadi kewajiban orang tua dalam menjaga, merawat, melindungi anaknya, jika tidak hal ini dapat mengakibatkan seorang anak tumbuh tidak terpelihara dan tidak terarah.

Setiap orang tua berkewajiban melakukan hadhanah, dan hadhanah dalam fiqh disebutkan dua periode bagi anak dalam hadhanah, yaitu periode sebelum mumayyiz dan periode mumayyiz. Periode sebelum mumayyiz adalah dari waktu lahir sampai menjelang umur 7 tahun atau 8 tahun. Pada periode ini umumnya seorang anak belum bisa membedakan antara yang bermanfaat dengan yang berbahaya bagi dirinya. Dan periode kedua adalah periode mumayyiz yang dimulai dari umur 7 tahun sampai menjelang baliq berakal. Pada masa ini secara sederhana seorang anak telah mampu membedakan mana yang berbahaya dan mana yang bermanfaat bagi dirinya. ${ }^{63}$ Dan terdapat perbedaan cara pengasuhan antara mumayyiz dan setelah mumayyiz.

Orang tua adalah penentu tumbuh kembang anak baik dari raga maupun jiwanya, seorang anak tidak akan mampu memenuhi kebutuhan hidup tampa bantuan dari orang tuanya, jika orang tua mengabaikan maka anak tidak akan tumbuh dengan sempurna, bahkan orang tua tidak merawat dan melindungi dengan baik. Anak akan menemui ajalnya, dan apabila orang tua tidak mendidik anak tersebut, anak akan menjadi orang yang bodoh juga dapat terjerumus kedalam kenistaan.

\footnotetext{
${ }^{62}$ Adnan Hasan Shalih Baharitis, Tangung Jawab Seorang Ayah Terhadap Anak LakiLaki (Jakarta: Gema Insani, 1996), 42.

${ }^{63}$ Satria Effendi M. Zein, Problematika Hukum Keluarga Islam Kontemporer, Analisis Yurisprudensi Dengan Pendekatan Ushuliyah (Jakarta: Prenada Media, 2010), 181-182.
} 
Pada dasarnya setiap anak lahir dalam keadaan suci dan memiliki segala potensi positif yang melekat padanya, baik potensi ahklak maupun agama. Semua potensi yang dimiliki anak akan berkembang sesuai dengan arahan yang diberikan orang tua sebagai lingkungan pertama yang berinteraksi dengannya. ${ }^{64}$

Oleh sebab itu orang tua wajib menanamkan nilai Islami kepada anak mulai dari dalam kandungan. Orang tua harus selalu memperhatikan prilakunya sendiri, dan senantiasa memberi contoh teladan dalam hal ibadah dan berahklak mulia, karena sebagai orang pertama yang berinteraksi dengan anak, maka anak akan mencontoh dan meniru apa yang dilakukan orang tuanya, dan harus senantiasa juga memantau prilaku anak. Dan juga menuntun anak untuk memiliki iman, Islam dan ahklah mulia. Hal ini dikarenakan tugas orang tua ini tidak hanya menentukan perilaku anaknya saja tetapi turut menentukan warna kepribadian seperti pemikiran, emosional, dan kejiwaan.

\section{Kewajiban Berlaku Adil Kepada Anak.}

Memperlakukan anak secara adil merupakan kewajiban orang tua dan merupakan hak seorang anak. Berlaku adil terhadap anak merupakan hal yang sangat penting. Para ahli penelitian pendidikan anak menyimpulkan bahwa faktor yang paling dominan terhadap timbulnya rasa hasud dalam diri anak adalah adanya pengutamaan saudara yang satu dengan yang lainnya. ${ }^{65}$ Sebagaimana firman Allah Swt dalam QS. Yusuf [12]: 7-9 berikut ini:

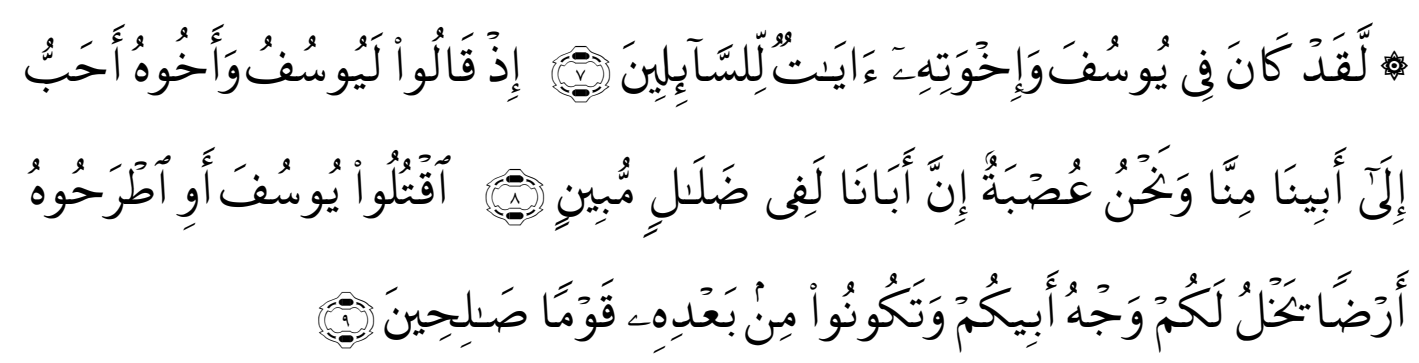

Terjemahnya:

"Sesungguhnya terdapat beberapa tanda-tanda kekuasaan Allah pada kisah Yusuf dan saudara-saudaranya bagi orang yang bertanya, yaitu ketika

${ }^{64}$ Yuni Setia Ningsih, Birrul Awlad Vs Birrul Walidain Upaya Pendidikan Emosi Anak Dalam Keluarga (Banda Aceh: Ar-Raniry Press, 2007), 34.

${ }^{65}$ Adnan Hasan Shalih Baharitis, Tangung Jawab Ayah Terhadap Anak Laki-Laki (Jakarta: Gema Insani, 2005), 59. 
mereka berkata, sesungguhnya Yusuf dan saudara kandungnya bunyamin lebih dicintai ayah kita padahal kita ini adalah satu golongan (yang kuat). Sesungguhnya ayah kita berada dalam kekeliruan yang nyata. Bunuhlah Yusuf atau buanglah dia kesuatu tempat yang tidak dikenal supaya perhatian ayahmu tertumpah kepadamu saja! dan setelah itu hendaklah kamu menjadi orang yang baik". ${ }^{66}$

Dari ayat tersebut dapat kita ambil hikmah terlalu menunjukkan kasih sayang kepada salah satu anak akan menimbulkan rasa benci di hati saudara yang lain apalagi hal ini dibarengi dengan prilaku zalim dan tidak adil maka tidak hanya anak yang di lebihkan yang di benci bisa saja anda sebagai orang tua juga di benci.

\section{Pola Asuh Anak Dalam Keluarga}

Keluarga merupakan sebuah lingkup kecil yang akan menghantarkan seseorang pada kehidupan bermasyarakat. Keluarga sebagai lembaga terkecil dalam masyarakat diharapkan mampu menyiapkan mental anak dalam menghadapi hidupnya di masa mendatang. Dengan kata lain keluarga harus mampu memberikan pendidikan akhlak, iman dan Islam.

Imam Zainal Abidin berkata, "hak anakmu adalah kamu menyadar bahwa ia adalah bagian dari dirimu dan disandarkan kepadamu dalam urusan dunia dan akhirat, baik dan buruk. Kamu bertanggung jawab atas kewajiban mengajarkan anakmu beribadah dan budi pekerti yang luhur. ${ }^{67}$ Menyuruh anak beriman dan berahklak mulia serta mengenalkannya pada sang pencipta, berbicara dengan baik tidak terlalu keras, bersabar atas segala sesuatu yang dapat menimpa, tidak memalingkan muka (karena sombong) berjalan di muka bumi dengan sederhana dan melunakkan suara jika berbicara. Untuk melaksanakan ketaatankepada Allah dalam hal ini orang tua diwajibkan untuk mengajarkan kepada anak, agar mendapat pahala atau siksa jika menghianatinya. ${ }^{68}$ Dan dalam menjalankan tugas ini orang tua dapat merujuk pada nasihat Luqman kepada anaknya.

\footnotetext{
${ }^{66}$ Departemen Agama RI, Al-Qur'an, 237.

${ }^{67}$ Rod Lahij, Dalam Buaian Nab Merajut Kebahagiaan Si Kecil: Cara Rasullah SAW Mendidik Dan Menyukseskan Anak (Jakarta: Zahra, 2005), 181.

${ }^{68}$ Salim Bahreisy dan H Said Bahreisy, Terjemahan Simngkat Ibnu Katsier (Surabaya: PT Bina Ilmu, 1990), 258.
} 
Allah SWT dalam Surat Luqman memberi gambaran tentang pola asuh anak, seperti wasiat Luqman kepada anaknya dimulai dengan pengenalan Allah. Yang maha Esa, (Ingatlah) ketika Luqman berkata kepada anaknya dan dia mengajarinya. Hai anakku, janganlah engkau menyekutukan Allah, sesungguhnya menyekutukan-nya adalah kezaliman yang besar, selanjutnya pesan (wasiat) diteruskan berkenaan dengan sikap kepada kedua orang tua.

Nasihat lain Luqman kepada putranya adalah: "Hai anakku, dirikanlah shalat dan suruhlah (manusia) berbuat kebaikan dan larang-lah mereka dari kemungkaran dan bersabarlah atas apa-apa yang menimpamu. Sesungguhnya yang demikian itu adalah urusan yang diutamakan. Akhirnya, Luqman berkata kepada putranya: "Sederhanalah dalam berjalan dan lunakkanlah suaramu, sesungguhnya seburuk-buruk suara adalah suara keledai" Kenyataannya, manusialah pencipta masa depannya. Jika dia selamat, maka lantaran kebaikankebaikannya dan jika celaka, maka lantaran keburukan- keburukannya. Dalam ayat lain juga mengatakan bahwa: "orang yang berdosa tidak akan memikul dosa orang lain. Dan jika seseorang yang berat dosanya memanggil orang lain untuk memikul dosa itu tidaklah dipikulkan untuknya sedikitpun meskipun yang dipanggil itu termasuk kerabatnya"

Semua ajaran Luqman itu bertumpu pada akidah yang benar dan akhlak mulia. Al-Qur'an menyebutkan-nya agar kita mengambil hikmahnya, karena hikmah adalah milik mukmin yang hilang. Surah Luqman ditutup dengan pengukuhan tanggung jawab kemanusiaan masa depan. ${ }^{69}$

Luqman Al-Hakim merupakan inspirator yang patut ditiru oleh setiap orang tua. Dia merupakan sosok lelaki terpercaya. Berpaling dari hal-hal yang haram dan menjauhi kata-kata keji dan tidak berarti. Tidak pernah menodai diri dengan dosa. Dalam hidupnya selalu menjaga kesucian. Dia tidak pernah menuruti keinginan hawa nafsu dan tergiur dengan kesenangan dunia, dan memiliki kesabaran yang luar biasa, Luqman selalu bertakwa kepada Allah, dan memberikan nasihat-nasihat yang penting untuk anaknya dalam menjalani

\footnotetext{
${ }^{69}$ Syeikh Muhammad Ghazali, Tafsir Tematik Dalam Al-Qur'an, Cet I (Jakarta: Gaya Media Peratama, 2004), 385-386.
} 
282 | MUSA WA, Vol. 11 No. 2 Desember 2019 : 253 - 288

kehidupan dan menghadapi akhirat, dan selalu mewanti-wanti anaknya agar selalu mengingat nasihatnya. ${ }^{70}$

Selain wasiat Luqman di atas, Rasulullah SAW juga memberi panutan kepada orang tua dalam pengasuhan anak. Beliau sangat mengasihi anak-anak. Beliau juga suka bercanda dengan anak-anak. Beliau meriwayatkan bahwa seorang anak harus diperlakukan sesuai dengan usianya, hal ini disebabkan pola pikir dan kecenderungan anak berbeda dengan orang dewasa, karena itu tidak boleh menuntut anak untuk serius terus menerus dan memberikan beban yang diatas kemampuan sianak. Dan tidak boleh pula melarang haknya, membatasi kesempatanya untuk bergembira dan bermain. Sebab Allah Swt telah menentukan ukuran segala sesuatu. ${ }^{71}$

\section{Pembagian Peran Dalam Pola Asuh Anak}

Pengasuhan seorang anak pada dasarnya merupakan tugas dan tanggung jawab kedua orang tua. Kedua orang tua harus saling bahu membahu dalam mengasuh anak. Akan tetapi di karenakan perbedaan tugas dalam rumah tangga membuat kedua orang tua memiliki tugas atau peran tertentu yang di tujukan pada masing-masing orang tua (ibu dan ayah).

a. Peran Ayah

Seorang ayah merupakan tulang punggung keluarga, dimana tugas seorang ayah adalah menafkahi seluruh anggota keluarganya. Hal ini berhubungan dengan tabiat lelaki yang tangguh dan berani dan juga ia memiliki kebebasan untuk bepergian tampa harus didampingi oleh mahramnya sehinga ia bisa mencari pekerjaan di luar untuk menafkahi keluarganya, selain itu kondisi fisik lelaki lebih tangguh sehinga dapat melakukan hal-hal yang tidak dapat dilakukan wanita. Sebagaimana firman Allah Swt dalam QS.Al- Baqarah: 233 berikut:

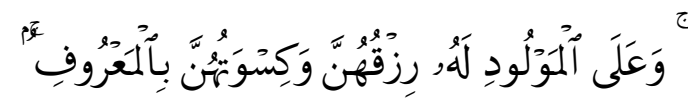

Terjemahnya:

"Dan kewajiban ayah memberi makan dan pakaian kepada para ibu

\footnotetext{
${ }^{70}$ Muhammad Ahmad Jadi Amuli, Kumpulan Kisah Dalam Al-Quran (Jakarta: Qorina, 2008), 319-320.

${ }^{71}$ Ibid.,
} 
dengan cara yang makruf'. ${ }^{72}$

Selain mencari nafkah Seorang ayah juga merupakan pelindung bagi keluarga, dimana seorang ayah harus mampu menjaga keluarganya dari hal-hal yang buruk serta memelihara keluarganya. Seorang ayah juga harus siap dalam memantau perkembangan anaknya. Hal ini karena masalah perlindungan terhadap anak, mengatur keperluan hidup mereka, mengarahkan mereka pada keterampilan dan pendidikan mereka. Dan juga masalah-masalah Hukum dan penegakan had, atau dalam fiqh dikenal dengan istilah Perwalian; maka kaum ayahlah yang lebih mampu menunaikanya. ${ }^{73}$ Kelebihan kaum ayah yang di anugerahkan kemampuan dan ketangguhan memungkinkan kaum ayah mengemban amanah ini.

b. Peran Ibu

Ibu merupakan orang yang memiliki tanggung jawab menjaga, merawat dan mentarbiyyah anak-anaknya. Seorang ibu pada permulaan hidup seorang anak sampai umur tertentu membutuhkan orang lain untuk membantunya dalam kehidupanya, seperti makan, minum, pakaian, membersihkan dirinya, bahkan sampai kepada pengaturan bangun dan tidur..

Oleh karena itu, orang yang menjaganya haruslah mempunyai keinginan kasih sayang, kesabaran dan mempunyai keinginan agar anak itu menjadi shaleh di kemudian hari. Di samping itu memiliki waktu yang cukup pula untuk melakukan tugas itu. Dan hal itu dimiliki oleh kaum ibu.

Hal ini karena tabiat wanita yang lembut dan penuh kasih sayang, serta wanita yang memiliki waktu dirumah. Karena wanita dalam agama Islam di anjurkan berada di rumah, sehingga tugas ini lebih cocok kepada kaum Ibu.

Selain merawat dan mengasuh serta mendidik anak, seorang ibu juga harus mampu mengawasi perkembangan fisik dan mental seorang anak. Ibu harus bisa memahami kejiwaan seorang anak sesuai tahap perkembangannya. Ibu tidak hanya menjadi seorang ibu melainkan juga seorang teman bagi si anak dalam berbagai masalah-masalah hidup yang ia hadapi.

\footnotetext{
${ }^{72}$ Departemen Agama RI, Al-Qur'an, 38.

${ }^{73}$ Muhammad Suwaid, Mendidik Anak Bersama Nabi:Panduan Lengkap Pendidikan Anak di sertai Teladan Kehidupan Para Salaf (Solo: Pustaka Arafah, 2003), 105.
} 
284 | MUSA WA, Vol. 11 No. 2 Desember 2019 : 253 - 288

Seorang ibu harus senantiasa sadar dan cerdas mengerti jiwa anakanaknya dan menghormati perbedaan karakter anaknya, dan kecendrungan anakanaknya. Sehingga dapat masuk kedalam jiwa anak dan menyelam kedalam dunia mereka yang masih jernih, untuk selanjutnya menanamkan nilai-nilai yang tinggi dan sifat-sifat terpuji serta aklakul karimah dengan menggunakan cara-cara yang baik dan juga seorang ibu harus peka terhadap hal-hal yang mempengaruhi perkembangan dan pembinaan anak, dan seorang ibu harus menghindari diri dari perkataan yang kurang baik terhadap anak atau menyumpahi anak, karena ditakutkan kata-kata seorang ibu akan terkabul. ${ }^{74}$

Seorang ibu juga harus jadi tauladan bagi anak dalam melaksanakan berbagai macam ibadah dan ahklak mulia dan juga senantiasa mendorong anakanaknya dalam beribadah dan membuat anaknya terbiasa beribadah kepada Allah dan juga ibu harus mampu melindungi anak dalam menjaga anak dari barangbarang yang dapat merusak akal dan akhlak anak, juga selalu mengingatkan anak memilih teman yang baik dan menghindari teman yang jahat. ${ }^{75}$

Seorang ibu harus mampu menjadikan anaknya orang-orang yang mengemban amanah Allah, dan seorang yang hebat dan tangguh, kita dapat mengabil suri tauladan dari Fatimah Az-Zahra. Ia membesarkan Hasan Husen dengan nilai-nilai Islam, penuh kasih sayang dan kedisiplinan serta senantiasa berlaku adil kepada anak, Fatimah Az-zahra mendidik Husain tentang pegorbanan dalam membela agama Allah, dan juga keteguhan dan juga berhasil mendidik Hasan sehingga ia menjadi orang yang teguh, dan bijaksana, memilih perdamaian dari pada peperangan. ${ }^{76}$ Dari contoh diatas dapat kita pahami bahwa ibu memiliki peran penting dalam kehidupan anak di saat ia dewasa.

${ }^{74}$ Labib Mz, Indahnya Rumah Tangga Sakinah (Surabaya: Putra Jaya, 2007), 146-152.

${ }^{75}$ Adil Fathih Abdullah, Wasiat Rasullah Kepada Kaum Wanita (Solo: Al-Qowam, 2005), 93-94.

${ }^{76}$ Ibrahim Amini, Fatmah Az-Zahra: Wanita Teladan Sepanjang Masa (Jakarta: Lentera, 2006), 66-67. 


\section{KESIMPULAN}

Pembentukan kepribadian sangat besar artinya, orang tua sebagai pembina pribadi yang pertama dalam hidup anak. Kegiatan Pengasuhan orang tua tidak hanya bagaimana orang tua memperlakukan anak, tetapi bagaimana cara orang tua mendidik, membimbing dan melindungi anak dari kecil hingga dewasa sesuai dengan nilai, norma dan kebudayaan masyarakat.

Pola asuh anak dalam hukum Islam (hadhanah) merupakan tangung jawab kedua orang tua yang harus mendapatkan perhatian khusus seperti; merawat, menjaga, mendidik serta membesarkan anak yang masih kecil dan belum dapat megurusi dirinya sendiri, juga orang tua haruslah mengawasi anak yang sudah berumur 7-18 tahun (remaja) atau masa setelah mumayyiz dari halhal yang dilarang oleh Syari'at, selain itu dalam melaksanakan tugas hadhanahnya setiap orang tua haruslah senantiasa berpedoman pada aturan Islam yang berdasarkan pada Al-Qur'an dan Al-Hadis.

\section{DAFTAR PUSTAKA}

Abdullah, Adil Fathih. Wasiat Rasullah Kepada Kaum Wanita. Solo: AlQowam, 2005

Ahmad Jadi Amuli, Muhammad. Kumpulan Kisah Dalam Al-Quran. Jakarta: Qorina, 2008

Ahmadi, Abu. Ilmu Sosial Dasar. Jakarta: PT Rineka Cipta, 1991

Amini, Ibrahim. Fatmah Az-Zahra: Wanita Teladan Sepanjang Masa. Jakarta: Lentera, 2006

Anak di sertai Teladan Kehidupan Para Salaf. Solo: Pustaka Arafah, 2003

Asya'rawi, Syaikh Mutawalli. Fikih Perempuan (Muslimah) Busana Dan Perhiasan, Penghormatan Atas Perempuan, Sampai Wanita Karier. Jakarta: Amzah, 2003

Bahreisy, Salim dan H Said Bahreisy, Terjemahan Simngkat Ibnu Katsier. Surabaya: PT Bina Ilmu, 1990

Barnadib, Sutari Imam. Pengantar Ilmu Pendidikan Sistematis. 
286 | MUSA WA, Vol. 11 No. 2 Desember 2019 : 253 - 288

Clemes, Harris. Mengajarkan Disisplin Kepada Anak. Jakarta: Mitra Utama, 1996

D. Gunarsa, Yulia Singgih. Psikologi Anak dan Remaja. Jakarta: BPK Gunung Mulia, 2002

Dalam Keluarga. Banda Aceh: Ar-Raniry Press, 2007

Daradjat, Zakiah. Pendidikan Islam Dalam Keluarga dan Sekolah Cet. II. Jakarta: CV. Ruhama, 1995.

Daradjat, Zakiah. Ilmu Jiwa Agama Cet. XVII. Jakarta: Bulan Bintang, 2009

Daradjat, Zakiah. Kesehatan Mental Cet. 10. Jakarta: GunungAgung, 1993

Departemen Agama RI, Al-Qur'an dan Terjemahnya Edsisi Ilmu Pengetahuan. Bandung: Mizan Pustaka, 2009

Departemen Agama RI. Alqur'an dan Terjemahnya. Jakarta: Toha Putra, 1999

Depdikbud. Kamus Besar Bahasa Indonesia. Jakarta: Bulan Bintang, 1996

Donelson, Elaine. Asih, Asah, Asuh, dan Keutamaan Wanita. Yogyakarta: Kanisius, 1990.

Effendi M. Zein, Satria. Problematika Hukum Keluarga Islam Kontemporer, Analisis, 2008

Ghazali, Syeikh Muhammad. Tafsir Tematik Dalam Al-Qur'an, Cet I. Jakarta: Gaya Media Peratama, 2004

Gunasa, Singgih D. Psikologi Perkembangan Anak dan Remaja. Jakarta: PT BPK Gunung Mulia, 1995

Hasan Shalih Baharitis, Adnan. Tangung Jawab Seorang Ayah Terhadap Anak Laki- Laki. Jakarta: Gema Insani,1996

Hendi dan Rahmadani Wahyu Suhendi. Pengantar Studi Sosiolog Keluarga. Bandung: CV Pustaka Setia, 2000

Hidayah, Arini. Televisi dan Perkembangan Sosial Anak. Yogyakarta: Pustaka pelajar, 1998

Hurlock Elizabeth, B. Perkembangan Anak Jilid II. Jakarta: Erlangga, 1995

Idris, Zahara dan Lisma Jamal, Pengantar Pendidikan. Jakarta: Gramedia, 1998 
Idris, Zahara dan Lisma Jamal. Pengantar Pendidika. Jakarta: Gramedia, Widiasarana, 2002

Ihsan, Fuad. Dasar-dasar Kependidikan. Jakarta: PT. Rineka Cipta, 2008

Indra, Hasbi. Dkk. Potret Wanita Shalehah . Jakarta: Pernamadani, 2004

Kartini, Kartini. Peran Orang Tua Dalam Memandu Anak. Jakarta: Rajawali, 1992

Lahij, Rod. Dalam Buaian Nab Merajut Kebahagiaan Si Kecil: Cara Rasullah SAW Mendidik Dan Menyukseskan Anak. Jakarta: Zahra, 2005

Majid Hasyim, Husaini A. Syarah: Riyadus Shalihin. Diterjemahkan Oleh: Mu'ammal Hamidi dan Imron A. Manan. Surabaya: PT. Bina Ilmu, 1993

Mansur. Pendidikan Anak Usia Dini dalam Islam.Yogyakarta: Pustaka Pelajar, 2005

Mardiya. Kiat Kiat Khusus Membangun Keluarga Sejahtera. Jakarta: BKKBN, 2002

Mz, Labib. Indahnya Rumah Tangga Sakinah. Surabaya: Putra Jaya, 2007

Nashiruddin Al-Albani, Muhammad. Ringkasan Shahih Bukhari Jilid 4. Jakarta: Pustaka Azzam, 2007

Ningsih, Yuni Setia. Birrul Awlad Vs Birrul Walidain Upaya Pendidikan Emosi Anak Pratama, 2004

Rakhmat, Jalaluddin Keluarga Muslim Dalam Masyarakat Modern. Bandung: PT. Remaja Rosdakarya, 1994

Riyanto, Theo. Pembelajaran Sebagai Proses Bimbingan Pribadi. Jakarta: Gramedia, Widiasarana Indonesia, 2002

Salam, Lubis. Menuju Keluarga Sakinah Mawaddah dan Warahmah . Surabaya: Terbit Terang, 2007

Seri Dan Mohsen Qaraati. Tafsir Untuk Anak Muda. Jakarta: Al-Huda, 2005

Shalih Baharitis, Adnan Hasan . Tangung Jawab Ayah Terhadap Anak Laki-Laki. Jakarta: Gema Insani, 2005

Shihab, M. Qurais. Tafsir Al-Misbah. Jakarta: Lentera, 2000 
288 | MUSAWA, Vol. 11 No. 2 Desember 2019 : 253 - 288

Thalib, M. 40 Tanggung Jawab Orang Tua Terhadap Anak. Bandung: Irsyad Baitus Salam, 1995

TIM Penyusun Kamus Pusat Pembinaan dan Pengembangan Bahasa. Kamus Besar Bahasa Indonesia. Jakarta, Balai Pustaka, 1988

Undang-undang perkawinan Nomor 1 Tahun 1974 pasal 1.

Yacoob, Abdul Monir dan Siti Shamsiah. Hukum Keluarga Islam. Jakarta: Kencana, 2006

Yatim Irwanto, Danny I. Kepribadian Keluarga Narkotika. Jakarta: Arcan, 1991

Yatim, Danny I. Kepribadian Keluarga Narkotika. Jakarta: Arcan, 1991

Yurisprudensi Dengan Pendekatan Ushuliyah. Jakarta: Prenada Media, 2010 